\title{
Hubungan Nilai Estimasi Laju Filtrasi Glomerulus dan Kadar Asam Urat Serum pada Subyek Penyakit Ginjal Kronik Non-Dialisis
}

\author{
${ }^{1}$ Jonathan Moula \\ ${ }^{2}$ Emma Sy. Moeis \\ ${ }^{2}$ Cerelia Sugeng
}
${ }^{1}$ Program Studi Pendidikan Dokter Fakultas Kedokteran Universitas Sam Ratulangi Manado
${ }^{2}$ Bagian Ilmu Penyakit Dalam Fakultas Kedokteran Universitas Sam Ratulangi Manado
Email: jonathan_pastrana99@yahoo.com

\begin{abstract}
Chronic kidney disease (CKD) is a global public health problem. The CKD Epidemiology Collaboration (CKD-EPI) equation is the most accurate result of GFR (eGFR) that has been evaluated in large varied populations and can be applied clinically in general. In CKD patient, uric acid excretion decreases linearly along the worsening renal function. This study was aimed to determine the relationship between serum uric acid level based on eLFG $_{\text {CKD-EPI }}$ value and eGFR CKD-EPI in non-dialysis CKD patients (male and female). This was an analytical study with a cross-sectional design using medical record data of CKD patients at Prof. Dr. R. D. Kandou Hospital from January to December 2016. There were 82 samples who met the inclusion criteria. The results showed that 45 of 54 males and 27 of 28 females with non-dialysis CKD had elevated serum uric acid levels. The correlation test between serum uric acid level and eLFG CKD-EPI value on males and females were $P=0.0$; $\mathrm{r}=-0.473$ and $P=0.0 ; \mathrm{r}=-0,598$ respectively. Conclusion: There was a significant negative relationship between serum uric acid level and eLFG CKD-EPI value in non-dialysis CKD patients for both sexes. Based on eLFG ${ }_{\text {CKD-EPI }}$ value, most patients had elevated serum uric acid levels.
\end{abstract}

Keywords: non-dialysis chronic kidney disease, serum uric acid, eLFG CKD-EPI

\begin{abstract}
Abstrak: Penyakit ginjal kronik (PGK) merupakan masalah kesehatan masyarakat global. Persamaan CKD-EPI (CKD Epidemiology Collaboration) adalah persamaan estimasi LFG (eLFG) yang paling akurat dan telah dievaluasi pada populasi beragam dalam jumlah besar dan dapat diterapkan pada penggunaan klinis secara umum. Pada pasien PGK, ekskresi asam urat menurun secara linier seiring dengan memburuknya fungsi ginjal. Penelitian ini bertujuan untuk mengetahui hubungan kadar asam urat serum berdasarkan nilai eLFG ${ }_{\text {CKD-EPI }}$ dan nilai eLFG CKD-EPI pada PGK non-dialisis (PGK-ND) baik pada jenis kelamin laki-laki maupun perempuan. Jenis penelitian ialah analitik dengan desain potong lintang menggunakan data rekam medik pasien PGK di RSUP Prof. Dr. R. D. Kandou periode Januari-Desember 2016. Terdapat 82 sampel yang memenuhi kriteria inklusi. Hasil penelitian mendapatkan 45 dari 54 laki-laki dan 27 dari 28 perempuan dengan PGK-ND mengalami peningkatan kadar asam urat serum. Uji korelasi hubungan antara kadar asam urat serum dan nilai eLFG $\mathrm{CKD}_{\text {-EPI }}$ pada jenis kelamin laki-laki dan perempuan masing-masing $P=0,0 ; \mathrm{r}=-0,473$ dan $P=0,0 ; \mathrm{r}=-0,598$. Simpulan: Terdapat hubungan negatif bermakna antara kadar asam urat serum dan nilai eLFG $_{\text {CKD-EPI }}$ pada kedua jenis kelamin. Pada sebagian besar pasien PGK-ND baik laki-laki mupun perempuan terdapat peningkatan kadar asam urat serum berdasarkan nilai eLFG CKD-EPI. $_{\text {. }}$ Kata kunci: penyakit ginjal kronis non-dialisis, asam urat serum, eLFG CKD-EPI
\end{abstract}


Penyakit ginjal kronik (PGK) merupakan masalah kesehatan masyarakat global dengan angka kejadian PGK yang meningkat, prognosis yang buruk, dan biaya yang tinggi. ${ }^{1,2}$ Data Indonesian Renal Registry (IRR) tahun 2015 melaporkan tercatat 30.554 pasien aktif menjalani dialisis pada tahun 2015, sebagian besar ialah pasien dengan PGK. Jumlah keseluruhan pasien PGK baru yang harus mendapat pelayanan dialisis pada tahun 2015 ialah 18.613 pasien atau sebesar $89 \%$ diikuti dengan pasien cedera ginjal akut sebanyak $7 \%$ dan pasien cedera ginjal akut pada PGK sebanyak 4\%. ${ }^{1,3}$ Riset Kesehatan Dasar (Riskesdas) 2013 menunjukkan prevalensi PGK di Indonesia yaitu sebesar $0,2 \%$, untuk Sulawesi Utara sendiri menduduki peringkat kedua bersama-sama Aceh dan Gorontalo sebesar 0,4\%. Secara nasional, prevalensi PGK berdasarkan jenis kelamin yaitu pada laki-laki $(0,3 \%)$ lebih tinggi dari perempuan $(0,2 \%) .{ }^{1,4}$

Penyakit ginjal kronik adalah abnormallitas struktur atau fungsi ginjal yang menetap lebih dari 3 bulan dengan implykasi pada kesehatan dan diklasifikasikan berdasarkan penyebab, kategori laju filtrasi glomerulus (LFG) dan kategori albuminuria. $^{2}$ Persamaan CKD-EPI (CKD Epidemiology Collaboration) adalah persamaan estimasi LFG (eLFG) yang paling akurat yang telah dievaluasi pada populasi beragam dalam jumlah besar dan dapat diterapkan pada penggunaan klinis secara umum. ${ }^{6}$

Asam urat adalah produk oksidasi terakhir dari metabolisme purin dan diekskresikan oleh ginjal. Hiperurisema didefinisikan sebagai kadar asam urat serum $>7,0 \mathrm{mg} / \mathrm{dL}$ pada laki-laki dan $>5,7$ $\mathrm{mg} / \mathrm{dL}$ pada perempuan. Penurunan LFG berkontribusi terhadap hiperurisemia, yang sering diamati pada pasien dengan PGK. Pada pasien PGK, ekskresi asam urat menurun secara linier seiring dengan memburuknya fungsi ginjal karena sekitar $70 \%$ asam urat diekskresikan dari ginjal. Meskipun terdapat kompensasi ekskresi melalui saluran cerna, peningkatan asam urat serum tidak dapat dihindari sehingga dapat menyebabkan terjadinya hiperurisemia. ${ }^{7-9}$ Penelitian ini bertujuan untuk mengetahui hubungan antara nilai eLFG dengan kadar asam urat serum pada pasien PGK non-dialisis (PGK-ND) di RSUP Prof. Dr. R. D. Kandou Manado.

\section{METODE PENELITIAN}

Jenis penelitian ini ialah analitik dengan desain potong lintang. Data diperoleh dari catatan rekam medik pasien PGK di RSUP Prof. Dr. R. D. Kandou periode Januari-Desember 2016.

Sampel penelitian yaitu pasien PGK non-dialisis (stadium 3-5ND) periode Januari-Desember 2016 yang terdiri dari semua data pasien PGK-ND periode Januari-Desember 2016. Kriteria inklusi dalam penelitian ini ialah PGK-ND (stadium 3-5ND), usia >18 tahun, serta laki-laki dan perempuan. Kriteria eksklusi ialah pasien dengan HIV positif, terapi OAT, dan terapi obat diuretik tiazid.

Data yang diperoleh dianalisis dengan menggunakan program melalui perangkat komputer. Uji statistik yang digunakan ialah uji deskriptif variabel penelitian dengan one-sample Kolmogorov-Smirnov, untuk mendapatkan nilai minimum, nilai maksimum, rerata, simpang baku dan distribusi normal dari seluruh variabel penelitian. Uji korelasi antara variabel bebas dan variabel tergantung menggunakan uji Spearman (distribusi data tidak normal), untuk mendapatkan nilai korelasi antara kadar asam urat serum dan nilai eLFG pada PGK-ND.

\section{HASIL PENELITIAN}

Setelah dilakukan pengambilan data, didapatkan 113 sampel pasien PGK-ND pada periode Januari-Desember 2016; 82 sampel memenuhi kriteria inklusi dan ekslusi penelitian.

Tabel 1 menunjukkan hasil uji deskriptif dan uji normalitas one-sample Kolmogorov-Smirnov untuk menilai distribusi data. Hasil yang didapatkan pada variabel usia ialah $P=0,2(P>0,05)$ yang menunjukkan data variabel usia terdistribusi normal. Untuk variabel lainnya (ureum, 
kreatinin, asam urat serum dan eLFG) didapatkan hasil $P<0,05$ yang menunjukkan data tidak terdistribusi normal sehingga dilanjutkan dengan uji Spearman.

Tabel 2 menunjukkan hasil distribusi jenis kelamin sampel berdasarkan kelompok usia. Didapatkan distribusi usia terbanyak pada kelompok umur $>65$ tahun yaitu 27 sampel dan yang tersedikit pada kelompok usia 18-24 dan 25-34 tahun yaitu
3 sampel masing-masing. Jumlah sampel laki-laki sebanyak 54 sampel dan perempuan sebanyak 28 sampel.

Tabel 3 memperlihatkan hasil distribusi PGK-ND berdasarkan eLFG CKD-EPI. $_{\text {. }}$ Didapatkan distribusi terbanyak pada kelompok derajat PGK 5-ND yaitu 44 sampel, diikuti oleh PGK 4 sebanyak 26 sampel dan PGK 3 sebanyak 12 sampel.

Tabel 1. Deskripsi variabel penelitian

\begin{tabular}{lcccccc}
\hline Variabel & n & Min & Max & Rerata & SB & Distr. \\
\hline Usia (tahun) & 82 & 18 & 86 & 57,87 & 14,329 & 0,200 \\
Ureum $(\mathrm{mg} / \mathrm{dL})$ & 82 & 33 & 561 & 151,94 & 114,367 & 0,000 \\
Kreatinin $(\mathrm{mg} / \mathrm{dL})$ & 82 & 1,4 & 25,4 & 5,9778 & 5,19393 & 0,000 \\
Asam urat serum $(\mathrm{mg} / \mathrm{dL})$ & 82 & 3,7 & 19,9 & 10,0738 & 3,15819 & 0,024 \\
eLFG $\left(\mathrm{ml} / \mathrm{mnt} / 1,73 \mathrm{~m}^{2}\right)$ & 82 & 2 & 59 & 16,54 & 12,366 & 0,002 \\
\hline
\end{tabular}

Tabel 2. Distribusi jenis kelamin berdasarkan kelompok usia

\begin{tabular}{cccc}
\hline \multirow{2}{*}{$\begin{array}{c}\text { Kelompok usia } \\
\text { (tahun) }\end{array}$} & \multicolumn{3}{c}{ Jenis kelamin } \\
\cline { 2 - 4 } & Laki-laki & Perempuan & Total \\
\hline $18-24$ & 1 & 2 & 3 \\
$25-34$ & 0 & 3 & 3 \\
$35-44$ & 5 & 0 & 5 \\
$45-54$ & 15 & 5 & 20 \\
$55-64$ & 14 & 10 & 24 \\
$>65$ & 19 & 8 & 27 \\
Total & 54 & 28 & 82 \\
\hline
\end{tabular}

Tabel 3. Distribusi PGK-ND berdasarkan eLFG ${ }_{\text {CKD-EPI }}$

\begin{tabular}{lcccc}
\hline Derajat PGK & $\begin{array}{c}\mathbf{e L F G}_{\mathbf{C K D}-\mathrm{EPI}} \\
\left(\mathbf{m l} / \mathbf{m i n}_{\mathbf{1}} \mathbf{1 , 7 3 \mathbf { m } ^ { 2 } )}\right.\end{array}$ & Laki-laki & $\begin{array}{c}\text { n }(\boldsymbol{\%}) \\
\text { Perempuan }\end{array}$ & Total \\
\hline PGK 3 & $30-59$ & 12 & 0 & 12 \\
PGK 4 & $15-29$ & 18 & 8 & 26 \\
PGK 5-ND & $<15$ & 24 & 20 & 44 \\
Total & & 54 & 28 & 82 \\
\hline
\end{tabular}

Tabel 4 memperlihatkan hasil distribusi kadar asam urat serum pada PGK-ND berdasarkan kelompok usia. Didapatkan hiperurisemia pada laki-laki sebanyak 45 sampel dan perempuan 27 sampel. Pada laki-laki terbanyak pada kelompok usia $>65$ tahun yaitu 17 sampel sedangkan pada perempuan terbanyak pada kelompok umur 55-64 tahun yaitu 9 sampel.

Tabel 5 memperlihatkan gambaran kadar asam urat serum berdasarkan eLFG ${ }_{\text {CKD-EPI }}$ pada PGK-ND. Untuk jenis kelamin laki-laki didapatkan pada eLFG 30$59 \mathrm{ml} / \mathrm{min} / 1,73 \mathrm{~m}^{2}$ terdapat 6 sampel 
normourisemia dan 6 sampel hiperurisemia sedangkan pada eLFG $15-29 \mathrm{ml} / \mathrm{min} /$ $1,73 \mathrm{~m}^{2}$, didapatkan 2 sampel normourisemia dan 16 sampel hiperurisemia. Pada eLFG $<15 \mathrm{ml} / \mathrm{min} / 1,73 \mathrm{~m}^{2}$ didapatkan 1 sampel normourisemia dan 23 sampel hiperurisemia.

Tabel 6 menampilkan gambaran kadar asam urat serum berdasarkan eLFGCKD-
EPI pada PGK-ND untuk jenis kelamin perempuan. Pada eLFG $30-59 \mathrm{ml} / \mathrm{min} /$ $1,73 \mathrm{~m} 2$ tidak terdapat sampel; pada eLFG $15-29 \mathrm{ml} / \mathrm{min} / 1,73 \mathrm{~m} 2$ didapatkan 1 sampel normourisemia dan 7 sampel hiperurisemia; dan pada eLFG $<15 \mathrm{ml} / \mathrm{min} /$ $1,73 \mathrm{~m} 2$ didapatkan 0 sampel normourisemia dan 20 sampel hiperurisemia.

Tabel 4. Distribusi kadar asam urat serum pada PGK-ND pada laki-laki dan perempuan berdasarkan kelompok usia

\begin{tabular}{cccccc}
\hline \multirow{2}{*}{$\begin{array}{c}\text { Kelompok usia } \\
\text { (tahun) }\end{array}$} & \multicolumn{5}{c}{ Kadar asam urat serum $(\mathbf{m g} / \mathbf{d L})$} \\
& \multicolumn{2}{c}{ Laki-laki } & \multicolumn{2}{c}{ Perempuan } & Total \\
\hline $18-24$ & 0 & 1 & 0 & 2 & 3 \\
$25-34$ & 0 & 0 & 0 & 3 & 3 \\
$35-44$ & 0 & 5 & 0 & 0 & 5 \\
$45-54$ & 4 & 11 & 0 & 5 & 20 \\
$55-64$ & 3 & 11 & 1 & 9 & 24 \\
$>65$ & 2 & 17 & 0 & 8 & 27 \\
Total & 9 & 45 & 1 & 27 & 82 \\
\hline
\end{tabular}

Tabel 5. Gambaran kadar asam urat serum berdasarkan eLFG ${ }_{\text {CKD-EPI }}$ pada PGK-ND dengan jenis kelamin laki-laki

\begin{tabular}{|c|c|c|c|}
\hline \multirow{2}{*}{$\begin{array}{c}\text { eLFG }_{\text {CKD-EPI }} \\
\left(\mathbf{m l} / \mathbf{m i n} / \mathbf{1}, \mathbf{7 3 m} \mathbf{m}^{2}\right)\end{array}$} & \multicolumn{3}{|c|}{ Kadar asam urat serum (mg/dL) } \\
\hline & $<7$ & $\geq 7$ & Total \\
\hline $30-59$ & 6 & 6 & 12 \\
\hline $15-29$ & 2 & 16 & 18 \\
\hline$<15$ & 1 & 23 & 24 \\
\hline Total & 9 & 45 & 54 \\
\hline
\end{tabular}

Tabel 6. Gambaran kadar asam urat serum berdasarkan elfg ckd-epi $_{\text {pada }}$ pgk-nd dengan jenis kelamin perempuan

\begin{tabular}{lccc}
\hline $\begin{array}{l}\text { eLFG } \\
\left(\mathbf{m l} / \mathbf{m i n} / \mathbf{1 , 7 3} \mathbf{~ m}^{\mathbf{2}}\right)\end{array}$ & \multicolumn{3}{c}{ Kadar asam urat serum $(\mathbf{m g} / \mathbf{d L})$} \\
\hline $30-59$ & 0 & $\geq 5$ & Total \\
\hline $15-29$ & 1 & 7 & 0 \\
$<15$ & 0 & 20 & 8 \\
Total & 1 & 27 & 20 \\
\hline
\end{tabular}

Tabel 7 memaparkan hasil uji korelasi Spearman terhadap eLFG dan kadar asam urat serum pada jenis kelamin laki-laki.
Hasil yang didapatkan ialah nilai $P=0,000$ dan nilai $r=-0,473$ yang menunjukkan terdapat hubungan bermakna antara kedua- 
nya. Nilai negatif pada $r$ menandakan adanya korelasi negatif yang berarti jika nilai salah satu variabel meningkat maka nilai variabel lainnya akan menurun.

Tabel 7. Analisis hubungan kadar asam urat serum dengan nilai eLFG CKD-EPI $_{\text {pada }}$ PGK-ND dengan jenis kelamin laki-laki

\begin{tabular}{lcc}
\hline Variabel & r & $\boldsymbol{P}$ \\
\hline eLFG & \\
Kadar KasI & $-0,473$ & 0,000 \\
\hline
\end{tabular}

Tabel 8 memaparkan hasil uji korelasi Spearman terhadap eLFG dan kadar asam urat serum. Hasil yang didapatkan ialah nilai $P=0,000$ dan nilai $\mathrm{r}=-0,598$ yang menunjukkan terdapat hubungan bermakna antara keduanya. Nilai negatif pada $r$ menandakan adanya korelasi negatif yang berarti jika nilai salah satu variabel meningkat maka nilai variabel lainnya akan menurun.

Tabel 8. Analisis hubungan kadar asam urat serum dengan nilai eLFG ${ }_{\text {CKD-EPI }}$ pada PGK-ND dengan jenis kelamin perempuan

\begin{tabular}{lcc}
\hline Variabel & r & $\boldsymbol{P}$ \\
\hline eLFG $_{\text {CKD-EPI }}$ & $-0,598$ & 0,000 \\
Kadar asam urat serum & & \\
\hline
\end{tabular}

\section{BAHASAN}

Penyakit ginjal kronik diklasifikasikan berdasarkan penyebab, kategori LFG, dan kategori albuminuria. ${ }^{2}$ Filtrasi glomerulus adalah proses fisiologik untuk menghasilkan ultrafiltrasi darah saat melalui kapiler glomeruli. LFG dipengaruhi oleh berbagai kondisi fisiologik dan patologik yang bervariasi. Persamaan CKD-EPI adalah persamaan eLFG yang paling akurat yang telah dievaluasi pada populasi beragam dalam jumlah besar dan dapat diterapkan pada penggunaan klinis secara umum. ${ }^{6}$

Pada Tabel 2, 3 dan 4 didapatkan bahwa jumlah pasien laki-laki yang menderita PGK-ND pada Januari-Desember 2016 di RSUP Prof. Dr. R. D. Kandou sebanyak 54 orang $(65,9 \%)$ dan pada perempuan sebanyak 28 orang (34\%). Hal ini menun- jukkan bahwa angka kejadian PGK-ND lebih tinggi pada jenis kelamin laki-laki dibandingkan jenis kelamin perempuan. Hasil Riskesdas 2013 juga mendapatkan hal serupa yaitu prevalensi pada laki-laki $(0,3 \%)$ lebih tinggi daripada perempuan $(0,2 \%)$. Hal ini tidak sejalan dengan temuan oleh Cobo et al. dan Goldberg et al. yaitu PGK cenderung lebih tinggi pada perempuan, sedangkan keparahan penyakit pada laki-laki lebih berat. Sebagian besar bukti dalam literatur saat ini menunjukkan tingkat perkembangan PGK yang lebih tinggi pada laki-laki, kecuali perempuan pasca menopause dan penyandang diabetes. Tingkat kematian pada pasien dengan PGK lebih tinggi di antara laki-laki. Fabbio et al. mengemukakan bahwa laki-laki umumnya memiliki prevalensi overweight yang lebih tinggi, lingkar pinggang yang lebih tinggi, dan tekanan darah tinggi, sedangkan perempuan memiliki prevalensi hematuria dan leukositosis yang lebih tinggi, yang merupakan manifestasi awal PGK. Temuan ini mendukung hasil studi sebelumnya dimana angka kejadian PGK lebih tinggi pada perempuan dan tingkat keparahan pada laki-laki. ${ }^{10}$

Pada Tabel 2 juga didapatkan distribusi usia penderita PGK-ND pada jenis kelamin laki-laki terbanyak ialah kelompok usia $>65$ tahun (27 sampel) sedangkan pada jenis kelamin perempuan didapatkan distribusi terbanyak pada kelompok usia 55-64 tahun (10 sampel). Tan et al. ${ }^{11}$ melaporkan bahwa pada orang dewasa yang berusia $\geq 66$ tahun dengan tingkat eLFG yang lebih rendah memiliki kejadian kumulatif terdiagnosis gout yang lebih tinggi dalam 3 tahun. Namun, orang-orang yang menjalani dialisis kronis memiliki insidensi gout yang lebih rendah dibandingkan dengan yang memiliki penurunan fungsi ginjal sedang. Laki-laki dan perempuan dengan eLFG 15$29 \mathrm{ml} / \mathrm{menit} / 1,73 \mathrm{~m}^{2}$ memiliki insidensi gout tertinggi, dengan 1 dari 30 perempuan lanjut usia dan 1 dari 20 laki-laki lanjut usia $\geq 66$ tahun mengalami gout dalam waktu 3 tahun. Studi oleh Tan et al. ${ }^{11}$ juga mendukung kejadian gout yang lebih tinggi pada pasien PGK dibandingkan dengan 
populasi umum dimana orang-orang dengan penurunan fungsi ginjal ringan sampai sedang (eLFG $45-59 \quad \mathrm{ml} / \mathrm{min} /$ $1,73 \mathrm{~m}^{2}$ ) memiliki lebih dari dua kali peningkatan risiko gout dibandingkan dengan orang dengan fungsi ginjal normal.

Pada Tabel 7 dan 8 disajikan hasil uji korelasi dari eLFG dan kadar asam urat serum. Uji korelasi yang digunakan ialah uji korelasi Spearman's-rho karena pada data variabel eLFG dan kadar asam urat serum tidak terdistribusi normal (Tabel 1). Nilai $P$ pada uji deskriptif one-sample Kolmogorov-Smirnov masing-masing didapatkan $P<0,05$. Dari hasil uji korelasi didapatkan adanya korelasi negatif yang bermakna antara nilai eLFG dan kadar asam urat serum pada kedua jenis kelamin. Jika salah satu nilai variabel meningkat maka nilai variabel lainnya akan menurun. Toyama et al. ${ }^{12}$ melaporkan bahwa pada pasien dengan nilai eLFG yang menurun didapatkan kadar asam urat serum yang meningkat hingga $>6,0 \mathrm{mg} / \mathrm{dl} .{ }^{12}$ Studi oleh Tsai et al. ${ }^{13}$ (2017) menyimpulkan bahwa penurunan eLFG terkait secara bermakna dengan kadar asam urat serum yang lebih tinggi terkait dan risiko peningkatan progresivitas PGK pada populasi Cina. Pengaruh hiperurisemia terhadap penurunan fungsi ginjal dan risiko progresivitas PGK lebih besar pada subyek tanpa proteinuria dibandingkan yang dengan proteinuria.

\section{SIMPULAN}

Terdapat hubungan negatif yang bermakna antara kadar asam urat serum dan nilai eLFG CKD-EPI pada PGK-ND pada kedua jenis kelamin. Sebagian besar pasien PGK-ND baik jenis kelamin lakilaki maupun perempuan memperlihatkan peningkatan kadar asam urat serum berdasarkan nilai eLFG ${ }_{\text {CKD-EPI. }}$

\section{SARAN}

Perlu dilakukan penelitian lebih lanjut untuk mencari faktor resiko lain yang dapat memengaruhi nilai eLFG $\mathrm{CKD}_{\mathrm{CPI}}$ dan kadar asam urat serum. Perlu juga dilakukan pemeriksaan fraksi eksresi asam urat.

\section{DAFTAR PUSTAKA}

1. Kementerian Kesehatan Republik Indonesia. Situasi penyakit ginjal kronis. InfoDATIN. 2017;: p. 1-4.

2. KDIGO CKD Work Group. KDIGO 2012 Clinical practice guideline for the evaluation and management of chronic kidney disease. Kidney International Supplements. 2013;3(1):1-150.

3. Indonesian Renal Registry (IRR). 8th Report of Indonesian Renal Registry, 2015; p. $1-45$.

4. Riset Kesehatan Dasar. Badan Penelitian dan Pengembangan Kesehatan Kementerian Kesehatan RI, 2013; p. 94-6.

5. Suwitra K. Penyakit Ginjal Kronik. In: Setiati S, Alwi I, Sudoyo AW, Setiyohadi B, Syam AF, editors. Buku Ajar Ilmu Penyakit Dalam (6th ed). Jakarta: Interna Publishing, 2014; p. 2159-65.

6. Levey AS, Inker LA, Coresh J. LFG estimation: from physiology to public health. Am J Kidney Dis. 2014;63(5): 820-34

7. Giordano C, Karasik O, King-Morris K, Asmar A. Uric acid as a marker of kidney disease: review of the current literature. Disease Markers. 2015;2015: $1-6$.

8. Nacak H, Diepen Mv, de Goeij MC, Rotmans JI, Dekker FW. Uric acid: association with rate of renal function decline and time until start of dialysis in incident pre-dialysis patients. BMC Nephrology. 2014;15(91):1-7.

9. Sarpal V. Serum uric acid level in patients with chronic kidney disease: a prospective study. Int $\mathbf{J}$ Sci Study. 2017;4(11):200-5.

10. Goldberg I, Krause I. The role of gender in chronic kidney disease. EMJ. 2016; 1(2):58-64.

11. Tan VS, Garg AX, McArthur E, Lam NN, Sood MM, Naylor KL. The 3year incidence of gout in elderly patients with CKD. Clin J Am Soc Nephrol. 2017;12:1-8.

12. Toyama T, Furuichi K, Shimizu M, Hara A, Iwata Y, Sakai N, et al. Relationship between serum uric acid levels and chronic kidney disease in a japanese cohort with normal or mildly reduced kidney function. PLoS ONE. 2015;10(9):1-11. 
Moula, Moeis, Sugeng: Hubungan nilai eLFG dan kadar asam urat serum ...

13. Tsai CW, Lin SY, Kuo CC, Huang CC.

Serum uric acid and progression of

kidney disease: a longitudinal analysis and mini-review. PLoS ONE. 2017; 12(1):1-16. 